10.2478/v10103-011-0018-y

\title{
Development of the Information Society in Czech Republic, Poland and Slovakia
}

\begin{abstract}
The article is presenting facts about the politics carried on the EU concerning development of the information society in Czech Republic, Poland and Slovakia - countries that in 2004 became members of the EU. Enlargement of the EU structures allowed for more dynamic development of these countries in the information society context. The situation of each country was presented by indicators describing the household and the community situation in information society. Indicators was gained from Eurostat system. The universality of these indicators lets to the assessment of the level and dynamics of development in relation to the EU average. Comparison of Poland and its southern neighbors allows also to observe changes that occur and may allow better progress in this field.
\end{abstract}

\section{Introduction}

The idea of building the information society results from theoretical assumptions, indicating that the information and knowledge are becoming increasingly important factor in building a knowledge-based economy. These assumptions lead to the debate on development of information society in Central Europe. Studies undertaken in this article include an analysis of indicators on information society in the Czech Republic, Poland and Slovakia. These

\footnotetext{
${ }^{*}$ Ph. D., University of Łódź
} 
countries, through membership in the European Union have the possibility of building a knowledge-based economy. This becomes possible by building a society that promotes and uses the knowledge available via the Internet and computers.

It becomes obvious that society open to innovation and knowledge allows for better management of these resources and facilitate the activities associated with use of knowledge to practical purposes. This approach is also becoming a driving force for socio-economic development of regions.

\section{The concepts of information society in European Union}

Regardless of the approach presented by the authorities in individual countries it must be noted that in the era information society, knowledge is becoming a driving force for all the transformations and improvements in quality of life. Data and the information, which are used in the appropriate way and converted by the experience and the human perception, becomes the basis of progress. It should be recognized that knowledge is characterized by (Drucker, 1994, p. 45; Castells, 2010, pp. 102-108):

- domination, which binds to its effective use;

- nonfinity, because the knowledge unlike different resources isn't subject to an effect of the wear and tear and its use leads to the achievement of snowball effect;

- simultaneity, which stems from the fact that the same knowledge can be used in many places at the same time;

- nonlinearity, involving the ability to achieve various effects using the same amount of knowledge;

- immeasurableness which manifests itself in an inability to measure knowledge directly;

- effects of scale, allowing for cutting of costs of knowledge.

The approach to the information society leads to the conclusion that the data and information derived from the environment with the use of information systems allow to generate knowledge, and in consequence the experience. This experience can be used as a competitive advantage of human individuals, either as part of building the competitiveness of the region or state. It should be emphasized that knowledge and experience derived from it are generated by human beings. This approach leads to understanding many problems in the field of activity of information society. 
Significant impact on the development of information society is connected with action picked up by the European Union, who is promoting the initiatives in this sphere. The beginning of action is bound with the initiative of the European Council around Corfu in 1994. At this time, the Bergman's Report was drawn up and its aim was familiarizing membership countries with the era of the information society. The assumptions of the report indicated that development of information and communication technologies can have a big impact on economic development, which was compared to the industrial revolution. The assumptions of the Bergman's Report arised from the theses of White Paper titled Growth, Competitiveness and Employment: The Challenges and Ways Forward Into the 21 st Century ${ }^{l}$, which showed a new approach to developing information society. (Horvath, 2010, p. 86)

Figure 1. Use of data and information to generate knowledge

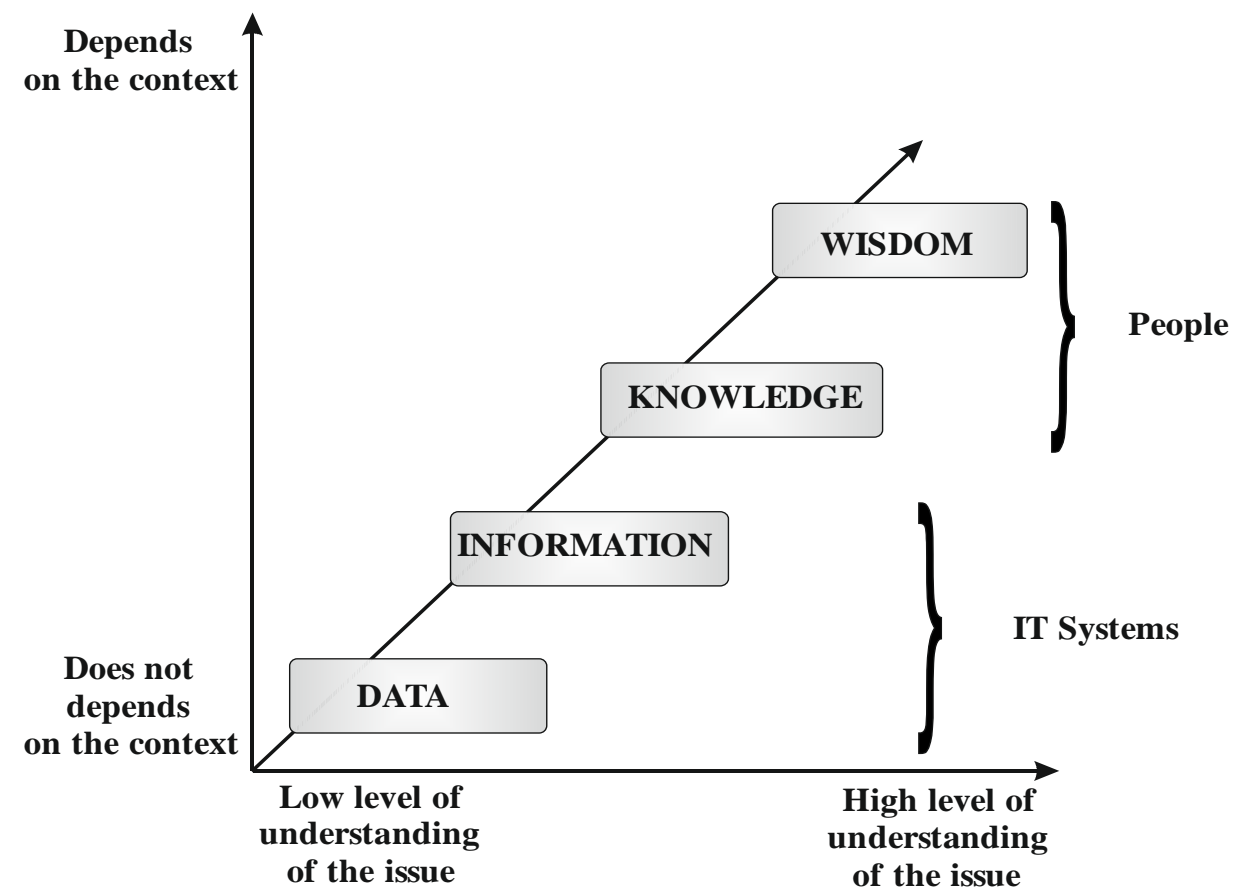

Source: Gospodarka oparta na wiedzy - stan, diagnoza i wnioski dla Polski. Ekspertyza Instytutu Zarządzania Wiedzą w Krakowie na zlecenie Ministerstwa Gospodarki, Warszawa Kraków 2002, p. 14.

\footnotetext{
${ }^{1}$ Brussels, 05.12.1993, COM (1993) 700 final.
} 
Another document, indicating an important role in developing the information society in Europe is the Green Paper from 1996 entitled Living and Working in the Information Society. People First ${ }^{2}$. It showed that ICT technologies are becoming more common, and their sophistication is growing incredibly fast. Thus the benefits of this kind of transformation were pointed out. It also highlighted some kind of anxiety concerning the decline in employment as an effect of ICT development but also the possibility of increasing the gap between industrialized and developing countries. Similar concerns were pointed in the increase in the gap between young and old generations.

An important stage in the development of information society was the Green Paper of 1998 entitled Public sector information: a key resource for Europe - Green Paper on public sector information in the information society ${ }^{3}$. It defined vision of development of computerization in public sector and the possible impact of this factor on the socio-economic sphere. The development of the public sector was supposed to take place by creating conveniences for the development of e-administration. Document presented the current development of IT in the public sector and pointed out the practical solutions for the implementation of public e-services. This approach required consideration at the EU level because of the divergent, legislation in many member countries.

An important element in building the information society in Europe was an initiative eEurope 2002. An Information Society For All ${ }^{4}$. Among its goals for the years 2000-2002 there were 64 targets, which included a wide range of actions for building the information society in all spheres of human activity. The document indicated weaknesses in building the information society hitherto registered. It was manifested in (base on eEurope 2002. An Information Society For All):

- insufficient access to the Internet with high parameters of the bandwidth;

- low level of the digitization of the society;

- inadequate culture of the usage of information technologies in management processes;

- low activity of the public sector in activities related to the development of e-services.

Most of objectives outlined in this document have been completed, which had a significant impact on the solution to the problems identified as weaknesses.

\footnotetext{
${ }^{2}$ Brussels, 24.07.1996, COM (1996) 389 final.

${ }^{3}$ Brussels, 20.01.1999, COM (1998) 585 final.

${ }^{4}$ Brussels, 08.12.1999, COM (1999) 687 final.
} 
The success of the European Commission led to the implementation of the new phase of the program in 2005 - eEurope 2005. An Information Society For $A l l^{5}$. Assumption of the program was to increase access to services based on the use of broadband computer networks. Document assumed a dynamic development of public services available via Internet. Development of this area have led to the creation of better conditions for development of entrepreneurship based on the electronic circulation of documents and broadband computer networks. eEurope 2005 program, similarly to earlier documents of the European Commission, has become a "roadmap" for opportunities of development based on funds from EU programs. An important element of this document were the guidelines on the legislation and carrying out research showing the potential of ICT usage in practice. Such an approach has led to increase the competitiveness of regions and thus, the entire European Union.

The next stage of in the information society policy in the European Union is associated with the implementation of guidelines published in the form of a strategic framework 2010 - A European Information Society for growth and Employment ${ }^{6}$. Implementation of the guidelines covered the years 2005-2010 and was based on the possibilities of information and communication technologies in the context of achieving a higher growth of qualitative and quantitative development of the EU economies. The guidelines indicate ICT as a factor enhancing social inclusion and raising standards of living. This documents continues the idea of building single European information space and supporting research in the field of innovation in ICT. The challenge posed to the member states was the creation of an integrated information society in Europe. This would contribute to the creation of new workplace while maintaining the principles of sustainable development promoted by the EU in all documents of Community.

Current guidelines relating to the development of information society are included in the document entitled Europe's Digital Agenda ${ }^{7}$. This document is part of Europe 2020 strategy. Agenda refers to the past experience in building the information society from earliest strategic documents, and outlines ways to increase living standards through the use of ICT in households and in business. This can be achieved through the use of economic and social potential of ICT. Agenda assumptions lead to a growing number of projects for the dissemination of broadband networks and increasing demand for services related to ICT. Such actions, are supposed to help to overcome barriers related to the digital

\footnotetext{
${ }^{5}$ Brussels, 28.05.2002, COM (2002) 263 final.

${ }^{6}$ Brussels, 01.06.2005, COM (2005) 229 final.

${ }^{7}$ Brussels, 26.08.2010, COM (2010) 245 final.
} 
economy, such as cybercrime, lack of investment in ICT infrastructure, lack of skills in the use of networks, lack of interoperability, or lack of adequate achievement in research and development.

Figure 2. Functioning of the digital economy

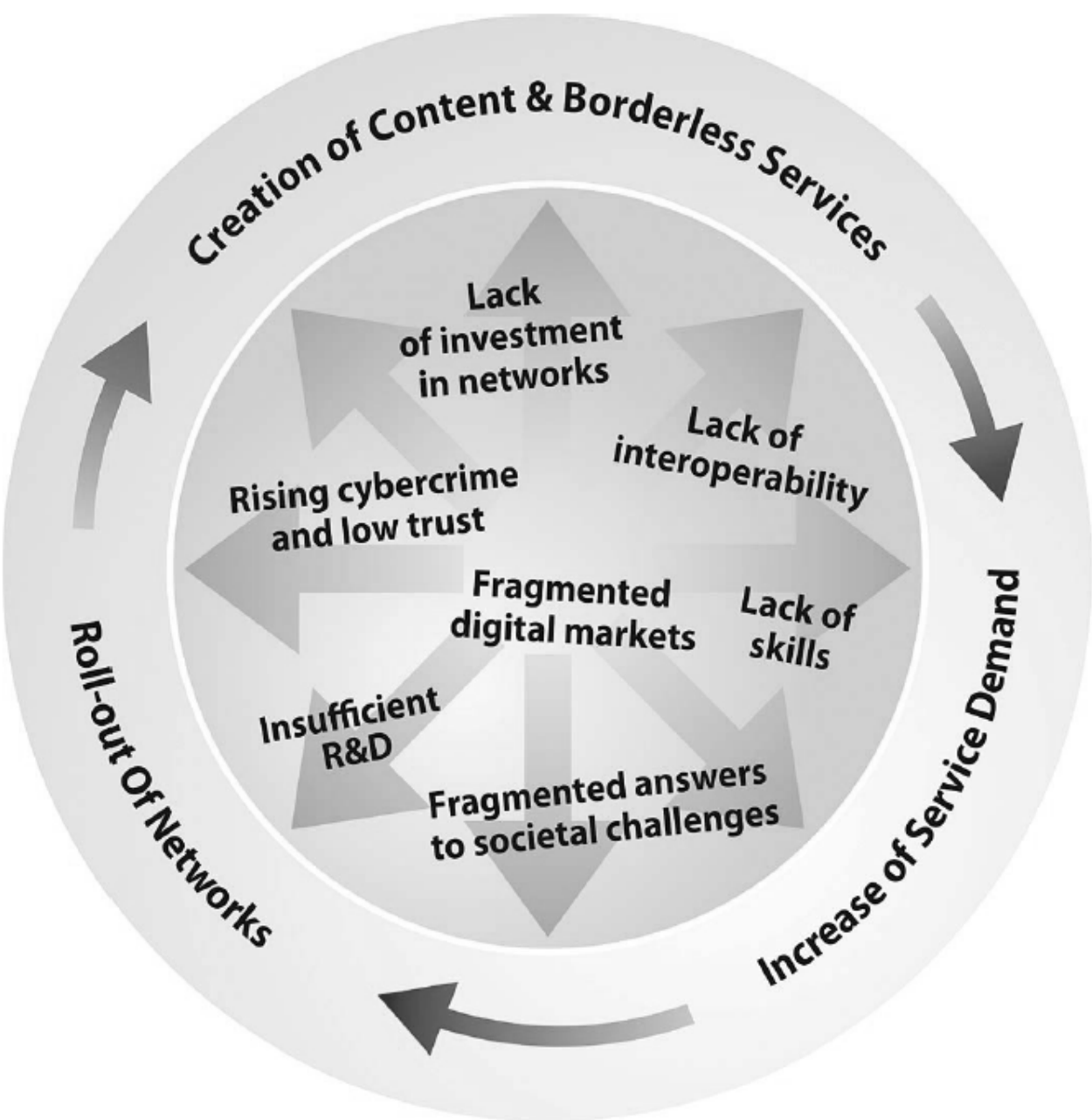

Source: Europe's Digital Agenda, p. 5.

The approach proposed by the European Union in all documents relating to the information society indicates a continuing desire to the development in this area. An important element is to indicate that the information society is related with some skills in certain conditions and a possibility of fast adapting to 
change. These changes affect both the social as well as economic sphere of life, with particular emphasis on R\&D.

\section{Information society development in selected countries of Central Europe}

The European Union is an organization that characterized by a dynamic and constantly socio-economical development. On 1 May 2004, EU enlargement included, inter alia, the countries of Central Europe and among them Poland, Czech Republic and Slovakia. This accession obliged them to boost the socialeconomic development, concerning also such aspect as the need to achieve the objectives of information society adopted by the EU policy.

Figure 3. Countries included in the analysis of the information society

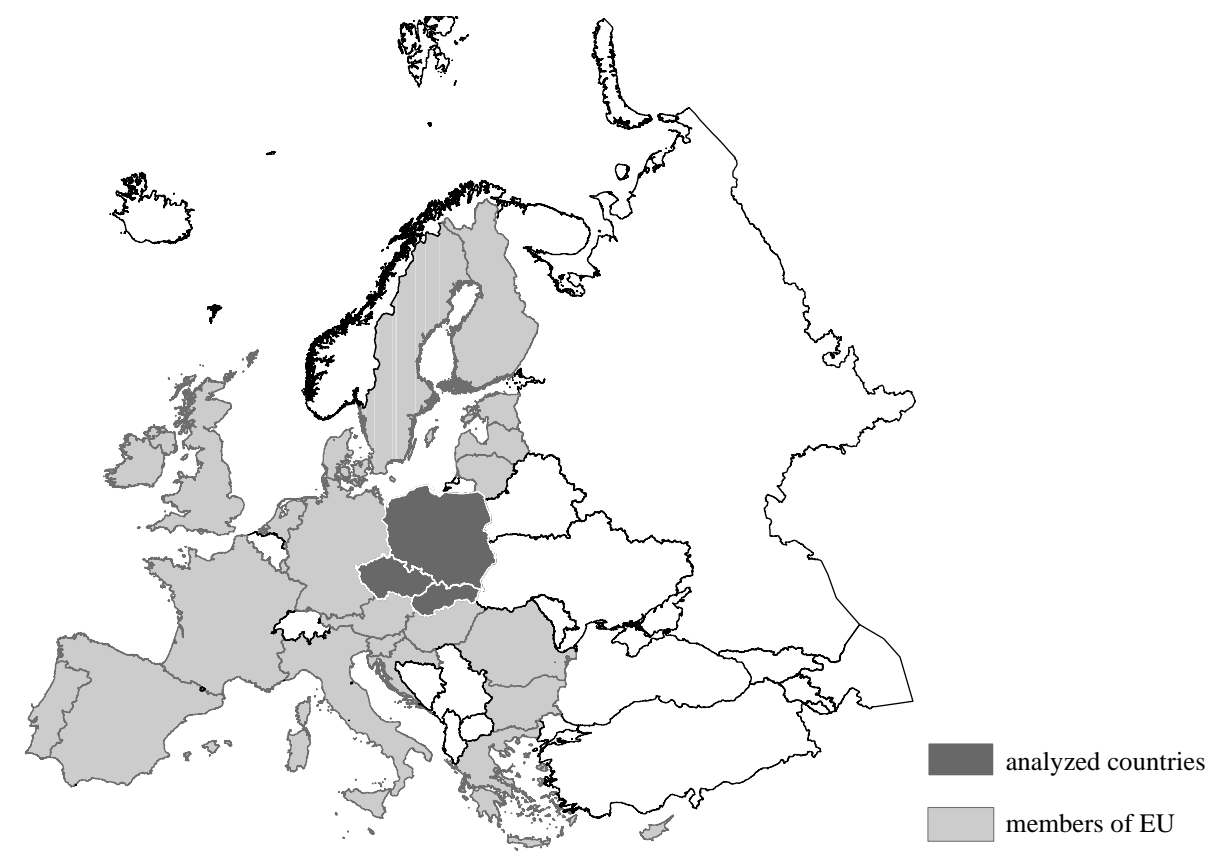

Source: Own composition.

In this article indicators describing the development of information society in the years 2006 to 2010 in countries mentioned above, will be 
analyzed $^{8}$. They relate to the social sphere, and computer techniques usage, in particular in households of the Czech Republic, Poland and Slovakia. The time scope of analysis is predicated on the availability of data of Eurostat database.

The basic and universal indicators describing the level information society development is the number of households with personal computer and the number of households using the Internet via personal computer. For the countries presented in this paper, constant growth of households with personal computer is observed. Data analyzed here indicate that the leader in this field is Slovakia, which in 2010 had $72 \%$ of households with a PC. In Poland the indicator reached the level of 69\%, and in Czech Republic only 59\%. All countries are characterized by similar dynamics index. But the fastest progress was recognized in Poland. From 2006 to 2010 this indicator changed about 25 percentage points.

\section{Figure 4. Households with a personal computer}

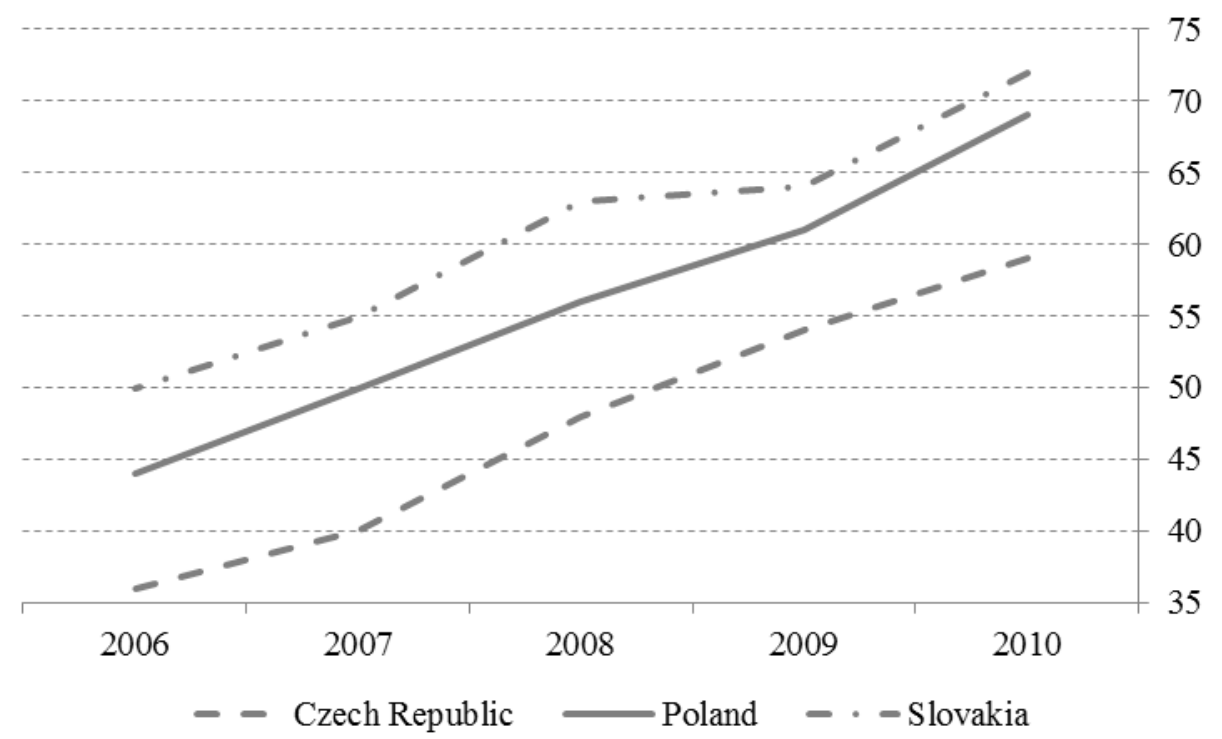

Source: Own calculations based on Central Statistical Office of Poland, Czech Statistical Office, Statistical Office of the Slovak Republic data.

In the context of information society development, another important indicator is that measuring Internet access. Among the analyzed countries, Slovakia noted the highest level of the percentage of households with Internet,

\footnotetext{
${ }^{8}$ Some indicators used data from the years 2007 to 2010.
} 
were $67 \%$ of those share was noted in 2010 . Also this country had noted the greatest dynamics of growth over the years $2006-2010$, despite the fact that in 2006 it was the state with the lowest value (27\%) of this indicator. This indicates increase of 40 percentage points. The second country in terms of dynamics growth is Czech Republic. In this country indicator increased by 32 percentage points. Least developed Internet access characterized Poland, where dynamics was measured on level of 27 percentage points.

Figure 5. Households with PC with the access to the Internet

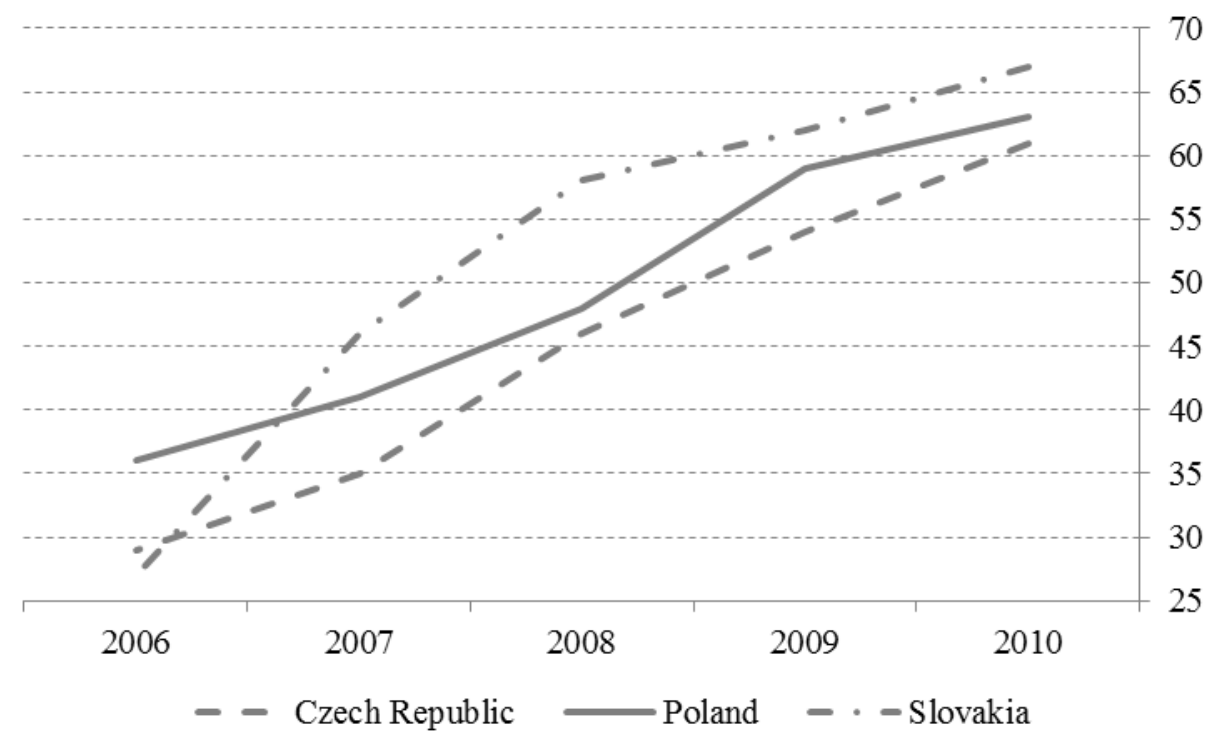

Source: Own study based on Eurostat data.

It should be stressed that all countries in 2006 were below the average rate of households with Internet access (49\% in the EU). The smallest delays in this area characterized Poland, where the level of the indicator was on the level of $36 \%$. The five-year period of analysis shows that in 2010 the number of households with the access to the Internet in the EU rose to $70 \%$. In 2010 none of the three countries did not reach the EU average for this indicator. The smallest delay was noted in Slovakia (67\%), next country was Poland (63\%). In the Czech Republic, presented indicator had a level of $61 \%$ of households.

Another important factor, influencing that quality and capabilities of Internet usage, is a broadband access. According to EU strategic documents relating to the development of information society all member countries should pursue to the development of broadband networks. These guidelines led to 
increasing the percentage of households with access to broadband Internet from $30 \%$ in 2006 to $61 \%$ in the last year of analysis.

Figure 6. Households with the broadband access to the Internet

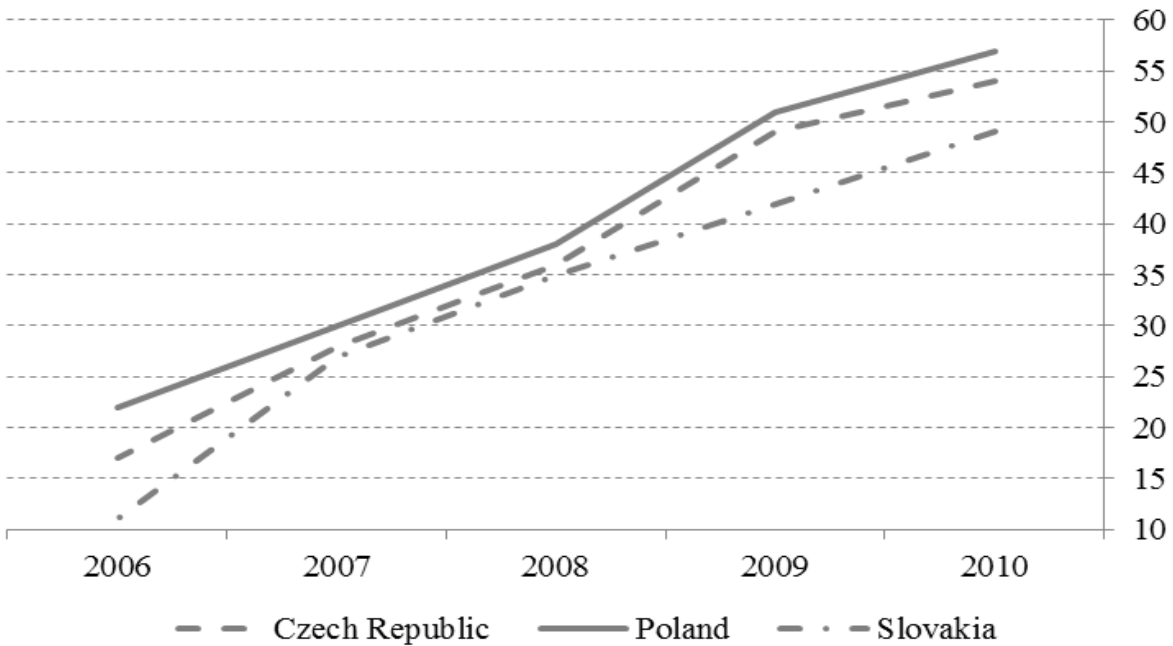

Source: Own study based on Eurostat data.

As with the ratio of households with access to the broadband Internet in 2006, the highest ratio was observed in Poland (22\%) and the lowest in Slovakia (11\%). In the Czech Republic, a share of $17 \%$ of households with the broadband access was identified. It should be emphasized that the highest growth trends over the years 2006 - 2010 was identified in Slovakia (38 percentage points increase), while the lowest growth rate characterized Poland (35 percentage points). Czech Republic noted an increase of 37 percentage points. What is more, none of the countries has reached the average level of this indicator in the EU yet. The smallest delay was observed in Poland and the greatest gaps in this measure, Slovakia, despite important growth.

Owning a computer and Internet access should be considered together with regular use of these elements in daily life. According to the Eurostat methodology, as individuals using the Internet regularly are recognized those who use it at least once a week. The average value of this indicator for the EU in 2010 was $65 \%$. 
Figure 7. Individuals using Internet regularly

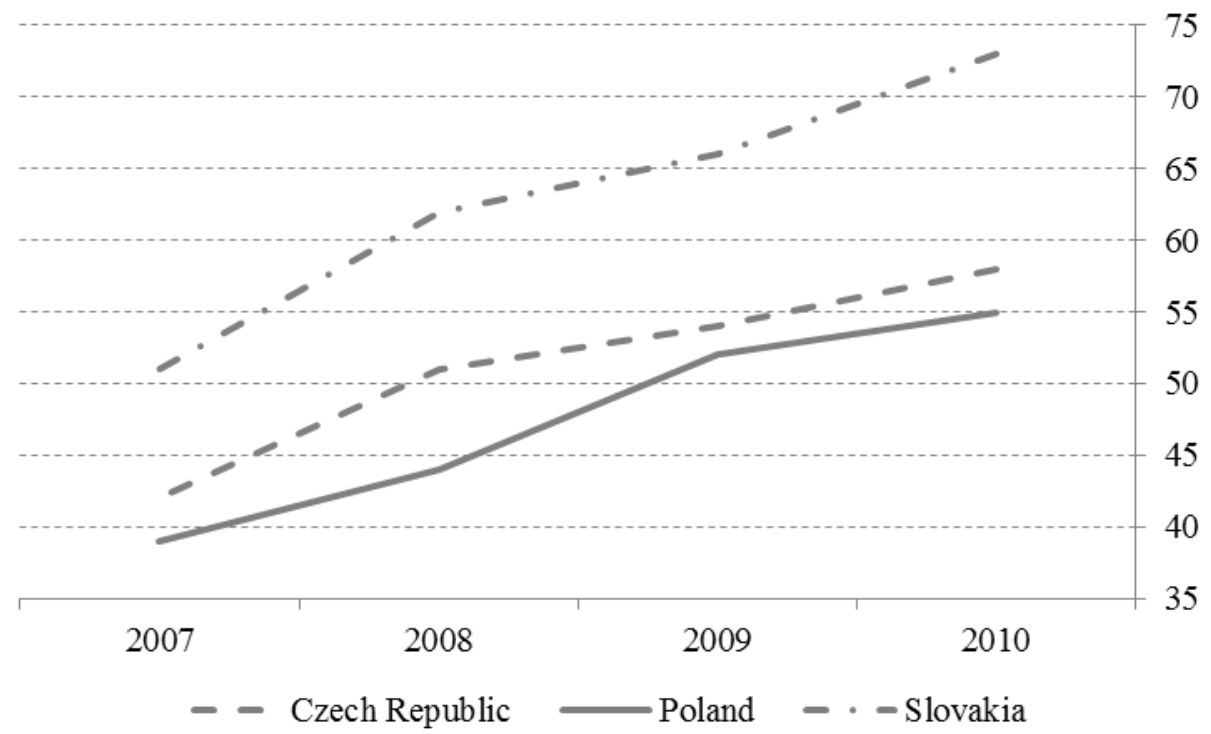

Source: Own study based on Eurostat data.

Indicator of Internet usage by analyzed countries shows that in the period 2007 - 2010, Slovaks used Internet mostly while Poles rarely. In Slovakia, in $2010,73 \%$ of the population used Internet regularly, what was a higher rate than the EU average. In the case of the Czech Republic this rate reached the level of $58 \%$, and in Poland only $55 \%$. The highest dynamics was noted in Slovakia, with an increase of 22 percentage points since 2007. In the Czech Republic and Poland dynamics is at the same level of 16 percentage points.

Using the Internet contributes to the raise of the quality of life and is a kind of convenience. What can serve as a measure in this case, it is society's activity in ordering of goods and services via Internet for private use. Obviously, EU countries observed a continuous increase of this index. In 2010, it reached the average level of $31 \%$ of EU citizens who ordered some goods or services via Internet in the last three months dating back from the date of the examination. 
Figure 8. Internet usage for ordering of goods and services

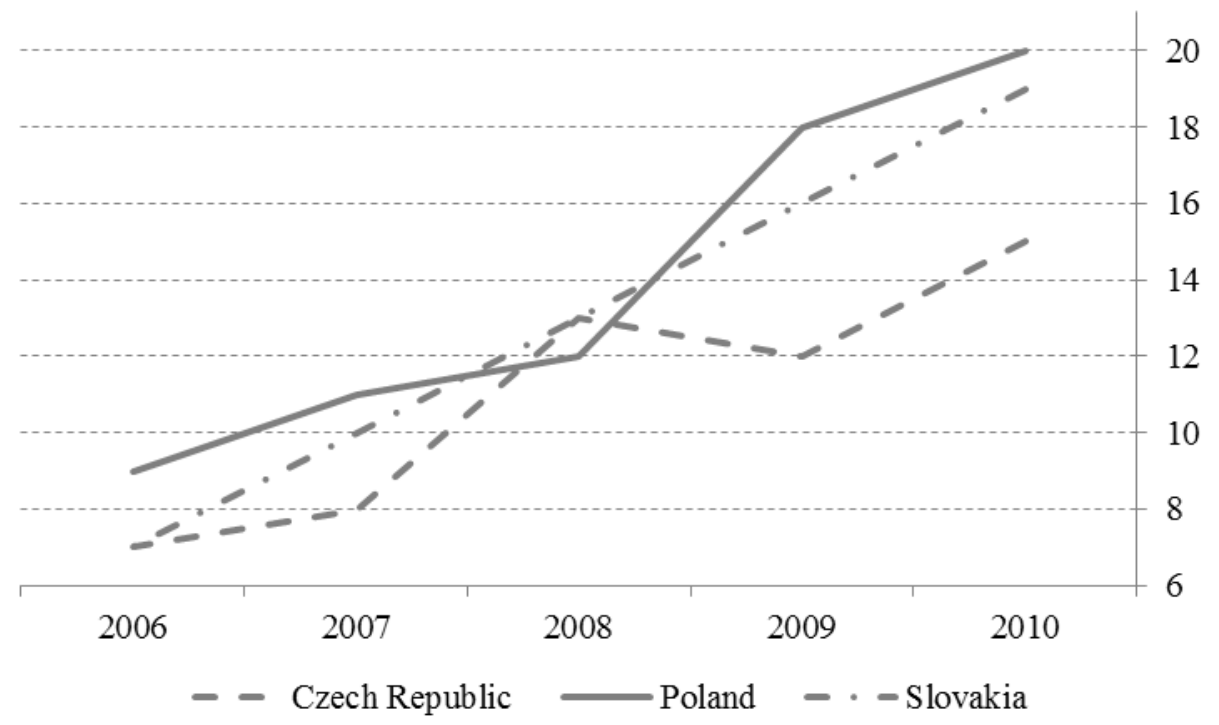

Source: Own study based on Eurostat data.

In the case of this index, there has been an increasing trend in all three countries over the whole period of examination. But it should be noted that in 2010 it was still below the EU average. The highest value of the indicator was observed in Poland (20\% of the population) and lowest in the Czech Republic $(15 \%)$. It shows to a reflection that in the period $2006-2010$, the greatest dynamics characterized Slovakia, which note an increase of 12 percentage points. Slightly weaker growth was observed in Poland (11 percentage points), while in the Czech Republic the increase was only 8 percentage points, contributing to the significant delay in relation to Poland, Slovakia and the rest of EU countries.

The use of Internet, is associated with the problem of the digital exclusion, which consists of, inter alia, lack of skills in using the Internet. All EU member states are obliged to reduction of this phenomenon, which in 2009 affected $30 \%$ of the EU community ${ }^{9}$.

\footnotetext{
${ }^{9}$ Data comes from: Eurostat regional yearbook 2010, European Union 2010.
} 
Figure 9. The level of digital exclusion

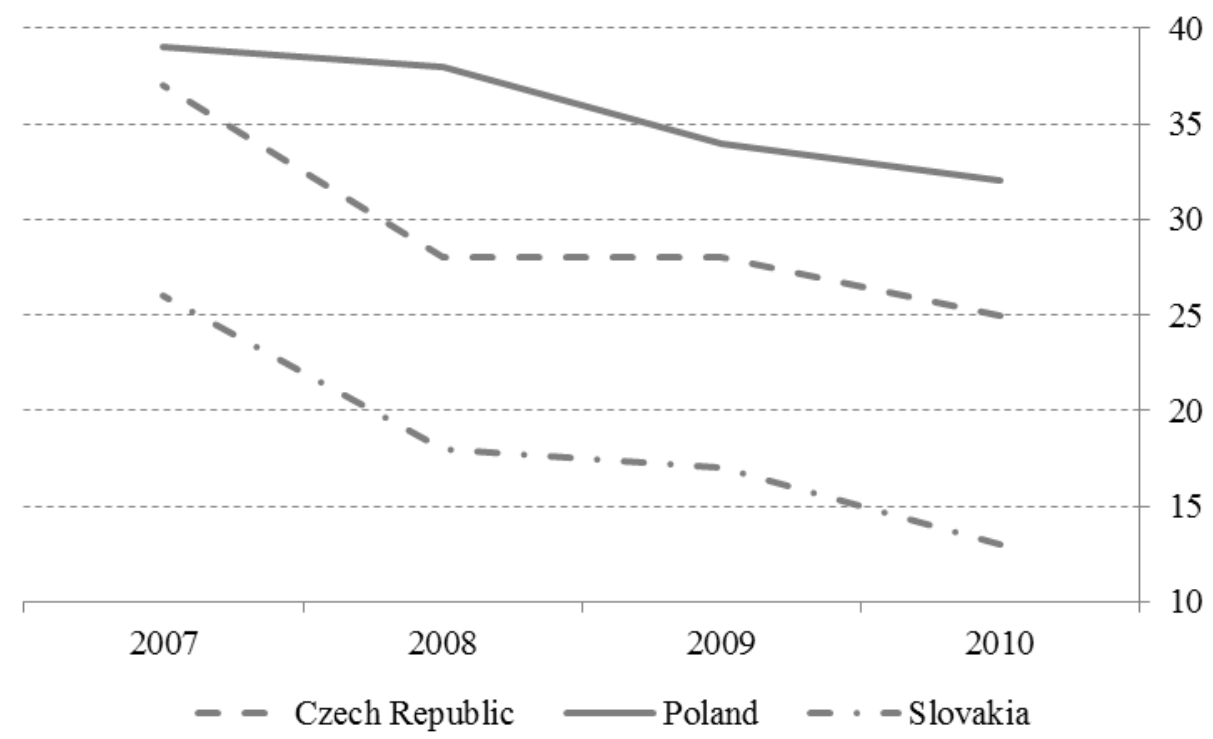

Source: Own study based on Eurostat data.

This phenomenon is also visible in the Czech Republic, Poland and Slovakia. The highest level of digital exclusion in 2007 was observed in Poland, where $39 \%$ of the population declared that never used Internet. In the Czech Republic this situation concerned $37 \%$ of the population. The lowest level of digital exclusion was noted in Slovakia, where $26 \%$ of the population did not have contact with Internet. Next years after EU accession showed decrease of this barrier of development. The largest dynamics of decrease characterized Slovakia, which due to a decrease of 13 percentage points, at 2010 showed a level of $13 \%$ of the digitally excluded. Slightly lower dynamics is observed in the Czech Republic, where decrease of 12 percentage points was noted. This problem is still visible in Poland where decrease was only 7 percentage points, and the exclusion rate in 2010 was $32 \%$.

\section{Conclusion}

An analysis of the level of information society development in Czech Republic, Poland and Slovakia showsthat these countries after their accession to the EU structures, are developing the sphere of information society. Thus, they 
are reaching the objectives of EU strategic documents, which indicate the need to develop ICT for better socio-economic development and prevent economic crisis in the future.

Another important aspect is activity of these three countries in the field of development of information society among households. Also, the increasingly lower levels of digital exclusion can be perceived as a positive element. Development of information society is the most dynamic in Slovakia, which is characterized by a large progress in the number of computers with Internet access and the use of this computers by the inhabitants of this country. Development of information society places Slovakia in a good light in relation to Poland and the Czech Republic.

Poland, despite a good situation at the beginning of the analyzed period of time, due to lowering dynamics of in this sphere, reduces its competitiveness in to the context of information society building. It should be noted however that the situation of Poland, despite the lower dynamics of development, compared to its southern neighbors is still looking good. However, there must be taken further action for information society development, in the coming years, otherwise Poland can lose the distance to Slovakia and the Czech Republic. In the case of Czech Republic, one should also expect the growing dynamics of information society development, because presented indicators show that this country has a lowest level of development.

An important issue is the aspiration of countries being a subject of research, to achieve the level of information society development at least at the EU average level. Next years should bring further development in this field, what in consequence should be the next step to achieve a higher level of competitiveness in terms of information society development.

\section{References}

Castells M. (2010), Społeczeństwo sieci, Wydawnictwo Naukowe PWN, Warszawa

Drucker P.F. (1994), Post-Capitalist Society, HarperBusiness, New York

eEurope 2002. An Information Society For All, Brussels, 08.12.1999, COM (1999) 687 final

eEurope 2005. An Information Society For All, Brussels, 28.05.2002, COM (2002) 263 final

Europe's Digital Agenda, Brussels, 26.08.2010, COM (2010) 245 final

Eurostat regional yearbook 2010, European Union 2010

Gospodarka oparta na wiedzy - stan, diagnoza i wnioski dla Polski. Ekspertyza Instytutu Zarzadzania Wiedza w Krakowie na zlecenie Ministerstwa Gospodarki, Warszawa - Kraków 2002 
Growth, Competitiveness and Employment: The Challenges and the Ways Forward into 21st Century, Brussels, 05.12.1993, COM (1993) 700 final

Horváth Z. (2010), New challenges of the information society [in:] Juridical Current, Vol. 13 Issue 1, p. 85-91

i2010 - A European Information Society for growth and employment, Brussels, 01.06.2005, COM (2005) 229 final

Living and Working in Information Society. People First, Brussels, 24.07.1996, COM (1996) 389 final

Public sector information: a key resource for Europe - Green Paper on public sector information in the information society, Brussels, 20.01.1999, COM (1998) 585 final

\section{Streszczenie}

\section{ROZWÓJ SPOŁECZEŃSTWA INFORMACYJNEGO W CZECHACH, POLSCE I SŁOWACJI}

Artykut prezentuje dane na temat prowadzonej w UE polityki w zakresie rozwoju społeczeństwa informacyjnego w Czechach, Polsce i Stowacji, które staty się członkami UE w 2004 roku. Rozszerzenie struktur unijnych pozwolito na zdynamizowanie rozwoju tych krajów w zakresie społeczeństwa informacyjnego. Sytuację poszczególnych krajów zaprezentowano przy pomocy wskaźników opisujacych gospodarstwa domowe oraz spoteczność pochodzqce z Eurostatu. Powszechność tych wskaźników pozwala na ocenę dynamiki rozwoju oraz poziomu tego rozwoju w odniesieniu do wartości średniej w UE. Porównanie Polski oraz jej południowych sqsiadów pozwolić ma również na dostrzeżenie przemian, które zachodzq $i$ moga pozwolić na lepszy postęp $w$ tej dziedzinie. 